Original Research Paper

\title{
Analytical Estimation of Geotherm for Multi Layer Model from Heat Flow Equation: A Case Study of Parts of Chad Sedimentary Basin, Nigeria
}

\author{
Emujakporue Godwin Omokenu \\ Department of Physics, University of Port Harcourt, Port Harcourt, Nigeria
}

Email: owin2009@yahoo.com

\begin{abstract}
The subsurface temperature distribution of part of Chad sedimentary basin has been determined by applying analytical solution for multi-layer-model in solving the 1-D steady state conductive heat flow equation. Four-layer model was adopted because the Chad basin is made up of four lithostratigraphies. In this model, equilibrium geotherm of the four layers was computed by considering each layer separately while the temperature and heat flow are matched across the boundaries. The solution was used for generating temperature for each of the formation. Computed minimum, maximum and average thermal conductivity and surface heat flow of the basin were used as the input parameters for the analytical solution. The estimated temperatures increase with depth within the sedimentary column. The estimated temperatures were compared with measured bottom hole temperatures from four deep wells in the basin and the result shows very good match for the following different scenarios; (1) when maximum thermal conductivities of each formations are combined with the maximum heat flow of $100 \mathrm{mWm}^{-2}$, (2) when the average thermal conductivities of each formation and the average heat flow of $85 \mathrm{mWm}^{-2}$ are used as input for the model and (3) when the minimum thermal conductivities of each formation and the minimum heat flow of $65 \mathrm{mWm}^{-2}$ are used as input for the model. The thermal structure of the sediment depends on its thermal conductivity, radiogenic heat sources, basal heat flow and surface temperature. The results of this research work have been used to effectively characterize the thermal structure of the study area.
\end{abstract}

Keywords: Geotherm, Analytical Modeling, Multilayer, Bottom Hole Temperature, Heat Flow

\section{Introduction}

The measurement of subsurface heat flow has been in active research. The spatial variation of computed terrestrial heat flow is an indication of the variation in subsurface temperature distribution and the pattern of the heat flow is directly controlled by the variation of rock thermal conductivity values as well as depths to heat sources. The sources of the heat flow in the subsurface are the heat flow from the earth's mantle due to the cooling of the earth and radiogenic heat production in the sediments (Turcotte and Schubert, 1980).

According to Beardsmore and Cull (2001) heat can be transferred by conduction, convection and radiation in sediments. Heat conduction is the major process of heat transfer in the crust and sediment while convection is the main process of heat transfer in the mantle (Cacace et al., 2010; Goff and Janik, 2000). Thermal conduction is the transfer of heat energy by contact due to thermal gradients. Thermal conductivity is the primary lithological factor controlling geothermal heat flow. In sedimentary basins, heat flow can also occurs through fluid flow of pore water, liquid petroleum and gas. These techniques are assumed to be negligible in this study. Heat flow in a sedimentary column is usually assumed to be vertically directed. Heat conduction in sediment is normally based on estimation of heat influx into the sediments and subsequent determination of temperature in the sediments.

Typically, subsurface heat flow is estimated from the product of the average thermal conductivity and geothermal gradient. One-dimensional (1-D) approach in which it is assumed that all heat flow is directed vertically upward in a sedimentary column is usually applied in estimating heat flow in a basin and it gives good estimate of temperature in the subsurface. The simplest $1 \mathrm{D}$ models are steady state solutions. Geothermal 
heat is responsible for some physical phenomenon such as mantle convections, plate tectonics, mountain building and thermal maturation of hydrocarbon in the subsurface (Beardsmore and Cull, 2001).

The direction of heat flow depends on temperature. The earth's temperature increases with depth and as a result heat flow from the subsurface to the earth surface (Mussett and Khan, 2000; Kaichi, 1984). In most geothermal research, subsurface temperatures are obtained from bottom hole or continuous temperature measured in wells drilled for oil or water exploration. The high cost and limited depth of drilling have make it difficult to execute direct and complete characterization of thermal regime in the subsurface. As a result, it is necessary to predict subsurface thermal thermal properties using different simple, easy and cheap techniques. Heat flow is commonly represented with Fourier heat flow equation. The heat flow equation can be solved by analytical or numerical method (Safanda, 1985; Stuwe, 2008).

In this research, analytical solution of 1-D conductive steady state heat equation for multilayer model was determined and applied for parts of the Chad Basin. The computed temperature distribution was used to characterize the thermal regime of the subsurface. The results of the research will be used as an aid for evaluating causes of possible observed heat flow anomalies in the subsurface. In this study, the subsurface temperature modelling will be based on available surface heat flow, surface temperature, thermal conductivity and heat production of the study area. Heat flow in a sedimentary basin depends on the thermal conductivity, heat production and basal heat flow into the basin (Turcotte and Schubert, 2002; Rudnick et al., 1998). Therefore, the objective of this study is to determine the subsurface temperature of the Chad basin by using analytical solution of the heat flow equation for a multilayer model. The computed subsurface temperatures will be compared with measured bottom hole temperatures.

\section{Summary of the Geology of the Chad Basin}

Chad sedimentary is located in north-eastern Nigeria (Fig. 1) and it extends into parts of Niger, Chad, Central African Republic and Cameroon. Nigerian Government in order to increase its hydrocarbon reserve base has been exploring for hydrocarbon in the basin for some years now.

The Chad Basin lies within Central and West Africa and covers an area of approximately $230,000 \mathrm{~km}^{2}$ (Fig. 2). The Chad basin is situated at the junction of basins that comprises the West African rift. The basin becomes active in early Cretaceous when Gondwana started to break up into component plates. The lithostratigraphy of the Chad basin has been described by some researchers (Okosun, 2000; Petters and Ekweozor, 1982). The Chad basin is made up of four lithostratigraphies (Table 1). They are Chad, Fika, Gongila and Bima Formations. The Chad Formation which is the uppermost formation in the basin consists of mudstone, muddy sandstone, sandstone and claystone. The Chad Formation is Pleistocene in age. The Chad Formation is underlies by Fika Formation which is made up of shale and thin limestone. The Gongila Formation lies beneath the Fika Formation. The Gongila Formation consists of sandstones, clays, shales and limestone layers. The Bima sandstone Formation is the basal part of the Chad basin. It is the oldest stratigraphic unit and it is made up of thin to thick beds of fine to coarse-grained sandstone.

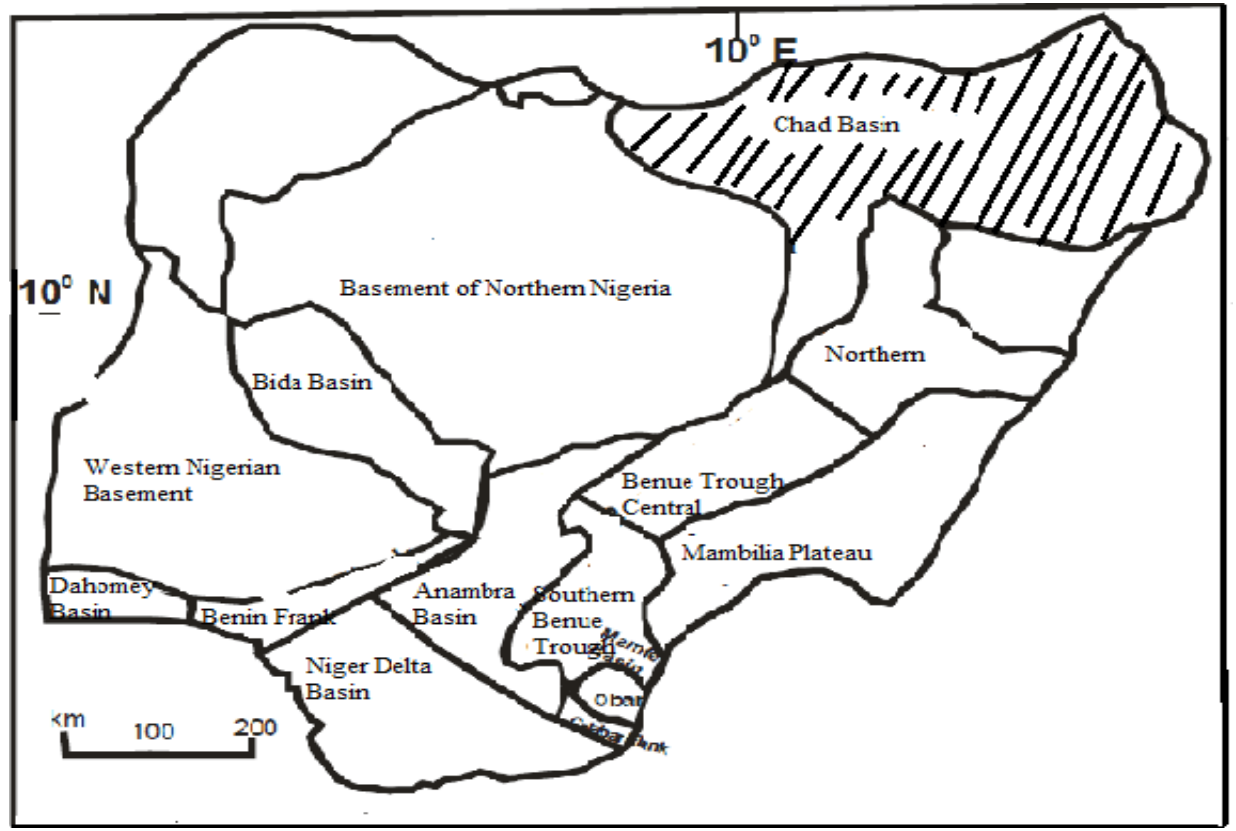

Fig. 1. Map of Nigeria showing the chad basin 


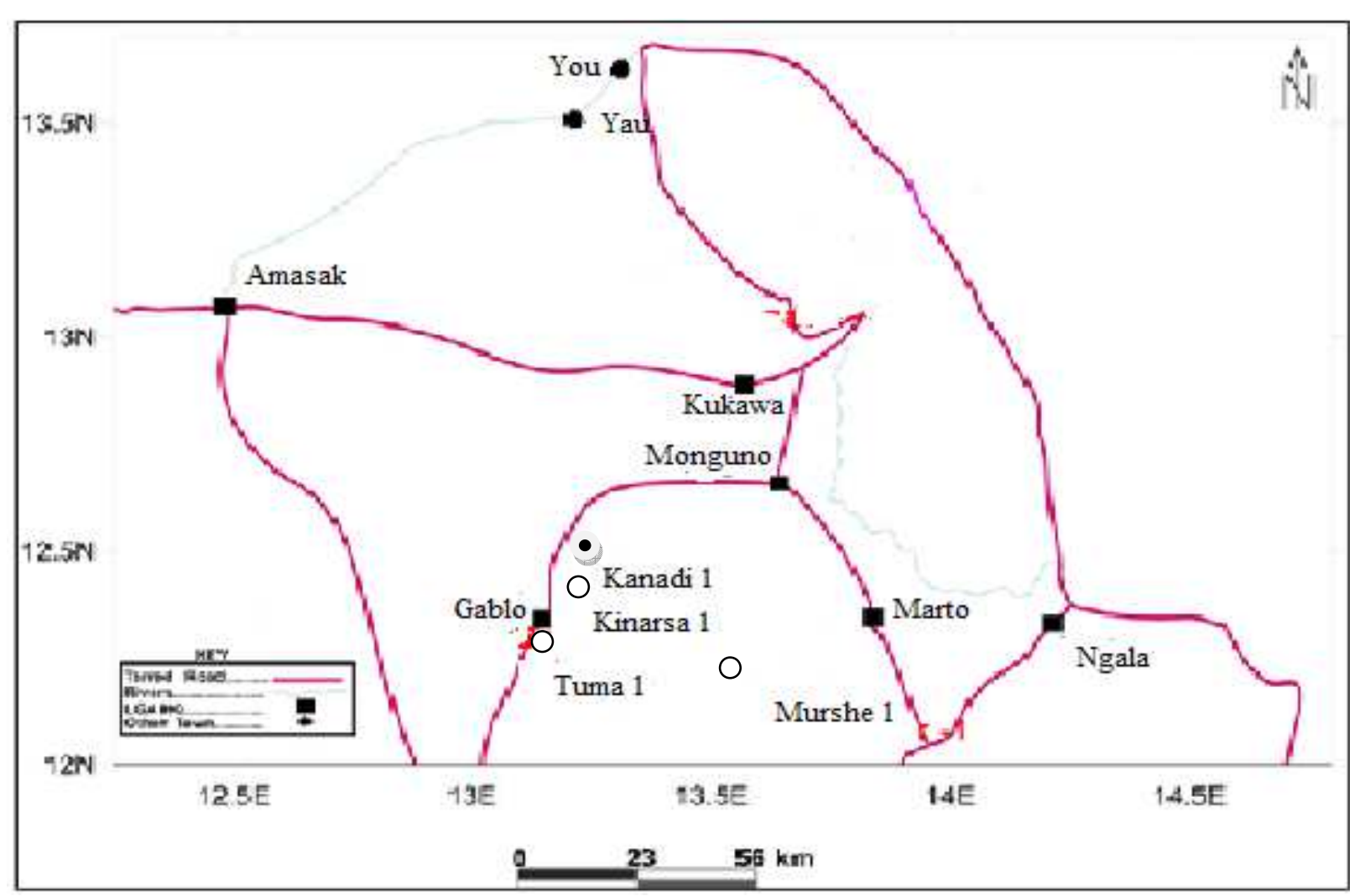

Fig. 2. Map of Chad basin showing some well Locations (Ali and Orazulike, 2010)

Table 1. Generalized stratigraphic column of the study area

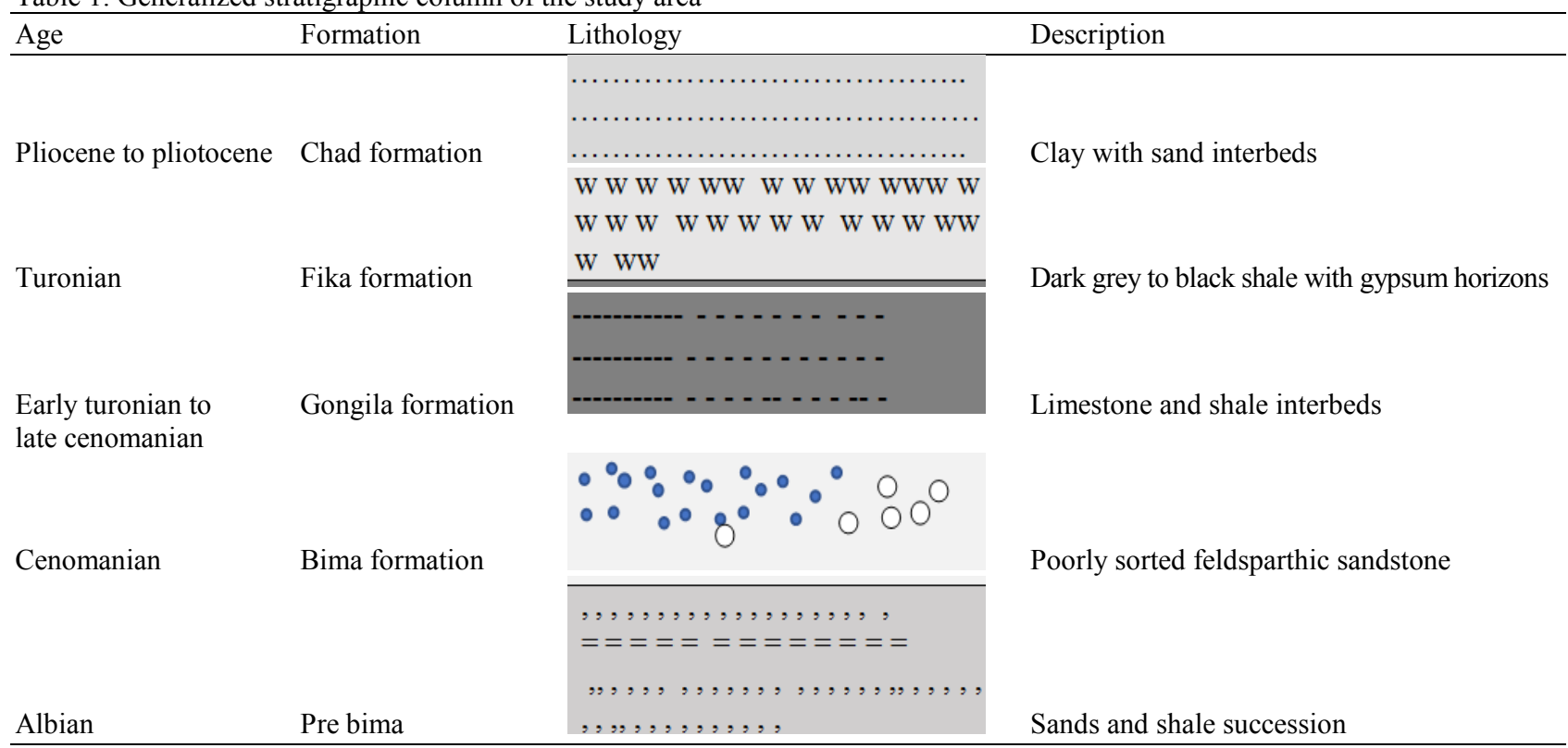

The model of regional framework and tectonic evolution of the Cretaceous-Pliocene rift basins of Niger, Chad and the Central African Republic has been presented by Genik (1992). The data revealed a complex series of Cretaceous grabens extending from Benue Trough to southwest. The data also indicates tectonic origin involving crustal thinning within and beneath the grabens and the near-surface presence of 
igneous intrusions within the horst/graben structures. The horst and graben structures are overlain by a relatively thick succession of sediments.

\section{Materials and Methods}

The steady state heat flow solution of Fourier equation provides an estimate of the subsurface temperature. The 1-D model make use of steady solution in which time dependence terms such as transient and convection effects are neglected. In this research multilayer solution was derived for the four lithostratigraphies in the Chad basin. The assumption is that the average bulk thermal conductivity of a formation is the same as the harmonic average of the various lithologies. The heat flow in a sedimentary basin is due to radioactive heat production in the sediment and heat flow from earth's interior (Lowrie, 2007). Multilayer heat flow model can be used for describing heat flow in a sedimentary basin that is made up of three or more formations. In this model, the equilibrium geotherm of the multilayer system is normally computed by considering each layer separately while the temperature and temperature gradients are matched across the boundaries. The Chad sedimentary basin is made up of four lithostratigraphies and therefore four-layer heat flow model will be adopted for the basin. The generalized heat conduction equation governing heat flow in the subsurface for a 3-D cartesian coordinate system (Stein, 1995; Gibson et al., 2008; Fowler, 2005) is given as:

$\rho C_{P} \frac{\partial T}{\partial t}=K\left(\frac{\partial^{2} T}{\partial x^{2}}+\frac{\partial^{2} T}{\partial y^{2}}+\frac{\partial^{2} T}{\partial Z^{2}}\right)+A$

Considering one-dimensional (1-D) sedimentary column where there is no erosion or sediment deposition and a constant heat flow, the sedimentary column will attain a state of thermal equilibrium in which the temperature at any point is steady. In this steady state:

$$
\frac{\partial T}{\partial t}=0
$$

Therefore Equation 1 reduces to:

$$
K\left(\frac{\partial^{2} T}{\partial x^{2}}+\frac{\partial^{2} T}{\partial y^{2}}+\frac{\partial^{2} T}{\partial Z^{2}}\right)+A
$$

In this case, the temperature-depth profile is called equilibrium geotherm. In a sedimentary basin, it is assumed that heat always flow in the vertical direction from the earth interiors. Therefore, neglecting the $x$ and $y$ coordinates, Equation 3 reduces to:

$$
\frac{\partial^{2} T}{\partial Z^{2}}=-\frac{A}{K}
$$

The Chad basin consists of four lithostratigraphies and the equilibrium geotherm for such models is calculated by considering each layer separately. The radiogenic heat production, $A$ in each of the four formation is given as:

$$
\begin{aligned}
& A=A_{1} \text { for } 0 \leq \mathrm{Z}<Z_{1} \\
& A=A_{2} \text { for } \mathrm{Z}_{1} \leq \mathrm{Z}<Z_{2} \\
& A=A_{3} \text { for } \mathrm{Z}_{2} \leq \mathrm{Z}<Z_{3} \\
& A=A_{4} \text { for } \mathrm{Z}_{3} \leq \mathrm{Z}<Z_{4}
\end{aligned}
$$

The equilibrium heat conduction equation for the first Formation, $0 \leq Z<Z_{1}$ is given as:

$$
\frac{\partial^{2} T_{1}}{\partial Z^{2}}=-\frac{A_{1}}{K_{1}}
$$

In the second layer, $z_{1} \leq z<z_{2}$, the equilibrium heatconduction equation is:

$$
\frac{\partial^{2} T_{2}}{\partial Z^{2}}=-\frac{A_{2}}{K_{2}}
$$

The equilibrium heat conduction equation for third formation, $Z_{2} \leq \mathrm{Z}<Z_{3}$ is given as:

$\frac{\partial^{2} T_{3}}{\partial Z^{2}}=-\frac{A_{3}}{K_{3}}$

And in the fourth layer $Z_{3} \leq Z<Z_{4}$, the equilibrium heat-conduction equation is:

$$
\frac{\partial^{2} T_{4}}{\partial Z^{2}}=-\frac{A_{4}}{K_{4}}
$$

Where:

$$
\begin{aligned}
& A_{i}=\text { Heat production in the ith sediment }\left(\mathrm{mWm}^{\square 3}\right), \\
& K_{i}=\text { Thermal conductivity of ith formation }\left(\mathrm{Wm}^{\square}{ }^{\circ} \mathrm{C}\right) \\
& i=1 \text { to } 4 \\
& T=\text { Temperature }\left({ }^{\circ} \mathrm{C}\right) \\
& Z=\text { Depth (m) }
\end{aligned}
$$

Equations 5 to 8 are second order differential equations and can be solved by integrating them twice and introducing boundary conditions. The temperature and heat flow are matched across the boundaries. 
Differentiating equation 5 twice and then applying the initial boundary conditions; surface temperature $T_{o}=$ $27^{\circ} \mathrm{C}$ at $z=0$ and surface heat flow $Q=-K \frac{d T}{\partial Z}=-Q_{0}, Z=0$ :

Then:

$$
\frac{\partial^{2} T_{1}}{\partial Z^{2}}=-\frac{A_{1}^{Z}}{K_{1}}+\frac{Q_{o}}{K_{1}}
$$

And:

$$
T_{1}=-\frac{A^{2} Z^{2}}{2 K Z^{2}}+\frac{Q_{o}^{Z}}{K_{1}}+27
$$

Similarly, by differentiating equation 6 twice and applying the boundary conditions; $\frac{\partial T_{1}}{\partial Z}=\frac{\partial T_{1}}{\partial Z}$ and $T_{2}=T_{1}$ at $Z_{1}$.

Then:

$$
\frac{\partial T_{2}}{\partial Z}=-\frac{A_{2}}{K_{2}} Z+\frac{Q_{o}}{K_{1}}-\frac{A_{2} Z_{1}}{K^{2}}-\frac{A_{1} Z_{1}}{K_{1}}
$$

And:

$T_{2}=-\frac{A_{2} Z^{2}}{2 K_{2}}+\left[\frac{A_{2} Z_{1}}{K^{2}}-\frac{A_{1} Z_{1}}{K_{1}} \frac{Q_{o}}{K_{1}}\right] Z+\frac{A_{1} Z_{1}^{2}}{2 K^{1}}-\frac{A_{2} Z_{1}^{2}}{2 K_{2}}+27$

Furthermore, by differentiating Equation 7 twice and applying the following boundary conditions $\frac{\partial T_{3}}{\partial Z}=\frac{\partial T_{2}}{\partial Z}$ and $T_{2}=T_{3}$ at $Z_{2}$.

Then:

$$
\frac{\partial T_{3}}{\partial Z}=-\frac{A_{2} Z}{K_{3}}+\frac{A_{3} Z_{2}}{K_{3}}-\frac{A_{2} Z_{2}}{K_{2}}+\frac{A_{2} Z_{1}}{K_{2}}-\frac{A_{1} Z_{1}}{K_{1}}+\frac{Q_{o}}{K_{1}}
$$

And:

$$
\begin{aligned}
& T_{3}=-\frac{A_{2} Z^{2}}{2 K_{3}}+\left[\frac{A_{3} Z_{2}}{K_{3}}-\frac{A_{2} Z_{3}}{K_{2}}+\frac{A_{2} Z_{1}}{K_{2}}-\frac{A_{1} Z_{1}}{K_{1}}+\frac{Q_{o}}{K_{1}}\right] \\
& Z+\frac{A_{3} Z_{2}^{2}}{2 K_{3}}-\frac{A_{3} Z_{2} Z_{3}}{K_{3}}+\frac{A_{3} Z_{2}^{2}}{2 K_{2}}+\frac{A_{1} Z_{1}^{2}}{2 K_{1}}-\frac{A_{1} Z_{1}^{2}}{2 K_{2}}+27
\end{aligned}
$$

Finally, by integrating the ordinary differential equation 8 twice and applying the boundary conditions $\frac{\partial T_{4}}{\partial Z}=\frac{\partial T_{3}}{\partial Z}$ and $T_{3}=T_{4}$ at $Z_{3}$.
Then:

$\frac{\partial T_{4}}{\partial Z} \frac{=-A_{4} Z}{K_{4}}+\frac{A_{4} Z_{3}}{K_{4}}+\frac{A_{3} Z_{3}}{K_{3}}+\frac{A_{3} Z_{2}}{K_{3}}$

$-\frac{A_{2} Z_{2}}{K_{2}}+\frac{A_{2} Z_{1}}{K_{2}}-\frac{A_{1} Z_{1}}{K_{12}}+\frac{Q_{o}}{K_{1}}$

And:

$$
\begin{aligned}
& T_{4}=-\frac{A_{4} Z^{2}}{2 K_{4}}+\left[\begin{array}{l}
\frac{A_{4} Z_{3}}{K_{4}}-\frac{A_{3} Z_{3}}{K_{3}}+\frac{A_{3} Z_{2}}{K_{3}}-\frac{A_{2}}{K_{2}} \\
-\frac{A_{1} Z_{1}}{K_{2}}-\frac{A_{1} Z_{1}}{K_{1}}+\frac{Q_{o}}{K_{1}}
\end{array}\right] \\
& Z+\frac{A_{4} Z_{3}^{2}}{2 K_{4}}+\frac{A_{3} Z_{3}^{2}}{2 K_{3}}+\frac{A_{3} Z_{2} Z_{3}}{K_{2}} \\
& +\frac{A_{2} Z_{1} Z_{3}}{K_{2}}+\frac{A_{3} Z_{2}^{2}}{2 K_{3}}-\frac{A_{3} Z_{2} Z_{3}}{K_{3}} \\
& +\frac{A_{2} Z_{2}^{2}}{2 K_{2}}+\frac{A_{1} Z_{1}^{2}}{2 K_{1}}-\frac{A_{2} Z_{1}^{2}}{2 K_{1}}-\frac{A_{2} Z_{1}^{2}}{2 K_{2}}+27
\end{aligned}
$$

In this study, equations $10,12,14$ and 16 were used for computing the subsurface temperature distribution for the four formations respectively.

\section{Results}

Some researchers have worked on the thermal properties of the basin. According to Nwankwo et al. (2009), the heat flow in the Chad sedimentary basin varies from 63.6 to $105.6 \mathrm{mWm}^{-2}$ with an average of $80.6 \mathrm{mWm}^{-2}$. The average surface temperature in the studied area is $27^{\circ} \mathrm{C}$. The radiogenic heat production in the Chad basin ranges between 0.17 and 1.90 $\mu \mathrm{Wm}^{-3}$ with an average of $0.9 \mu \mathrm{Wm}^{-3}$ (Ali and Orazulike, 2010). Dieokuma et al. (2013), calculated the thermal conductivity of the formations in the Chad basin and the results of their findings is shown in Table 2. The computed values of surface heat flow, radiogenic heat production, thermal conductivities, surface temperature and average thickness of the formations were used for estimating the subsurface temperature distribution in the study. The temperature was computed for different scenarios base on the minimum, maximum and average values of the thermal properties. The result of the subsurface temperature distribution is shown in Fig. 3-5 for the different scenarios. In all, a total of nine geotherms were generated. The assumed average thickness of the Chad, Fika, Gongila and Bima formations are 800, 700,1200 and $3100 \mathrm{~m}$ respectively. The total thickness of the sediments in the basin is approximately $5000 \mathrm{~m}$. 
Emujakporue Godwin Omokenu / Physics International 2016, 7 (2): 44.52 DOI: $10.3844 /$ pisp.2016.44.52

Table 2. Depth range, lithology, stratigraphic units and thermal conductivity of some wells in Borno-Chad Basin (Dieokuma et al., 2013)

\begin{tabular}{lllll}
\hline Well name & $\begin{array}{l}\text { Depth range } \\
(\mathrm{m})\end{array}$ & Lithology & $\begin{array}{l}\text { Lithostratigrahic } \\
\text { units }\end{array}$ & $\begin{array}{l}\text { Thermal conductivity } \\
\left(\mathrm{W} / \mathrm{m}^{\circ} \mathrm{C}\right)\end{array}$ \\
\hline Kasade-1 & $0-840$ & Sandstone & Chad formation & 2.055 \\
& $840-1190$ & Sanstone/shale & Fika formation & 1.895 \\
& $1190-1420$ & Shale & Gongila formation & 2.382 \\
Herwa-1 & $0-510$ & Sandstone & Chad formation & 2.854 \\
& $510-1520$ & Sandstone/Shale & Fika formation & 2.860 \\
& $1520-2190$ & Sandstone/Shale & Gongila formation & 2.557 \\
Kermar-1 & $0-500$ & Sandstone & Chad formation & 2.283 \\
& $560-680$ & Sandstone/Shale & Fika formation & 2.542 \\
Albarka-1 & $2850-3450$ & Sandstone/Shale & Bima formation & 2.830 \\
\hline
\end{tabular}

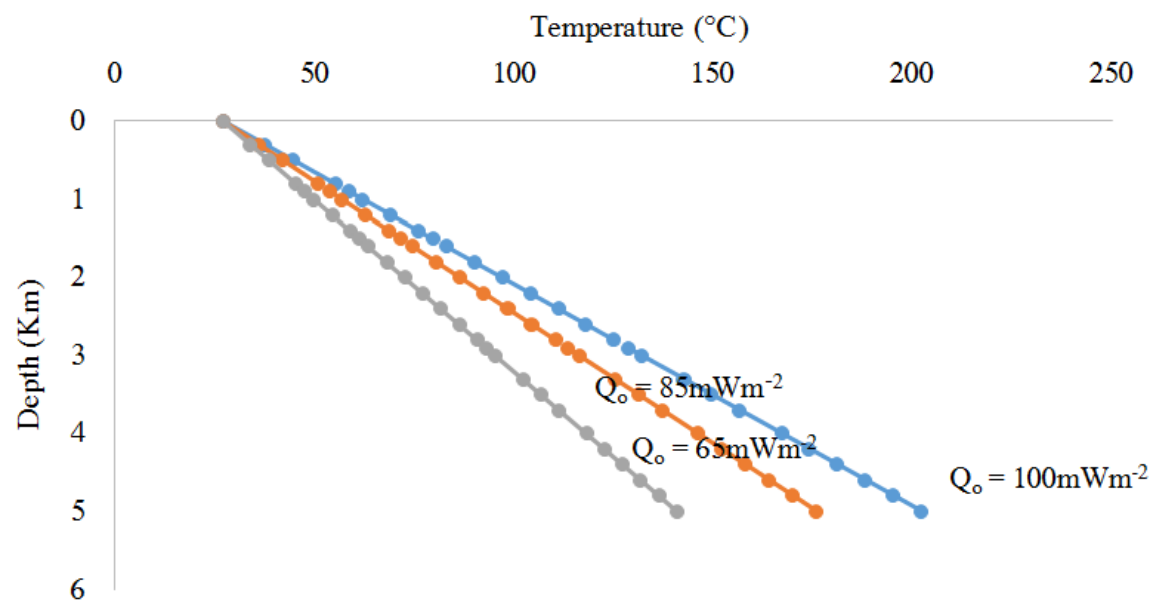

Fig. 3. Geotherm profile for maximum thermal conductivity

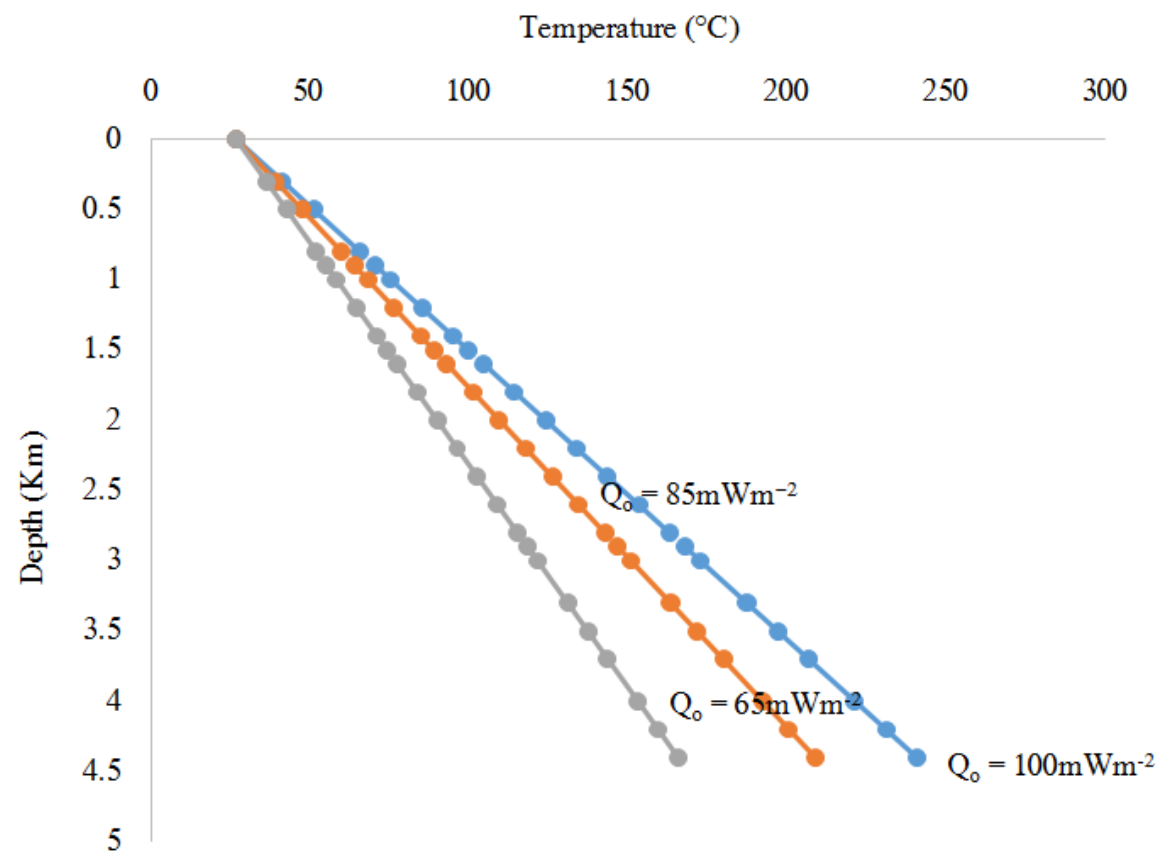

Fig. 4. Geotherm profile for minimum thermal conductivity 


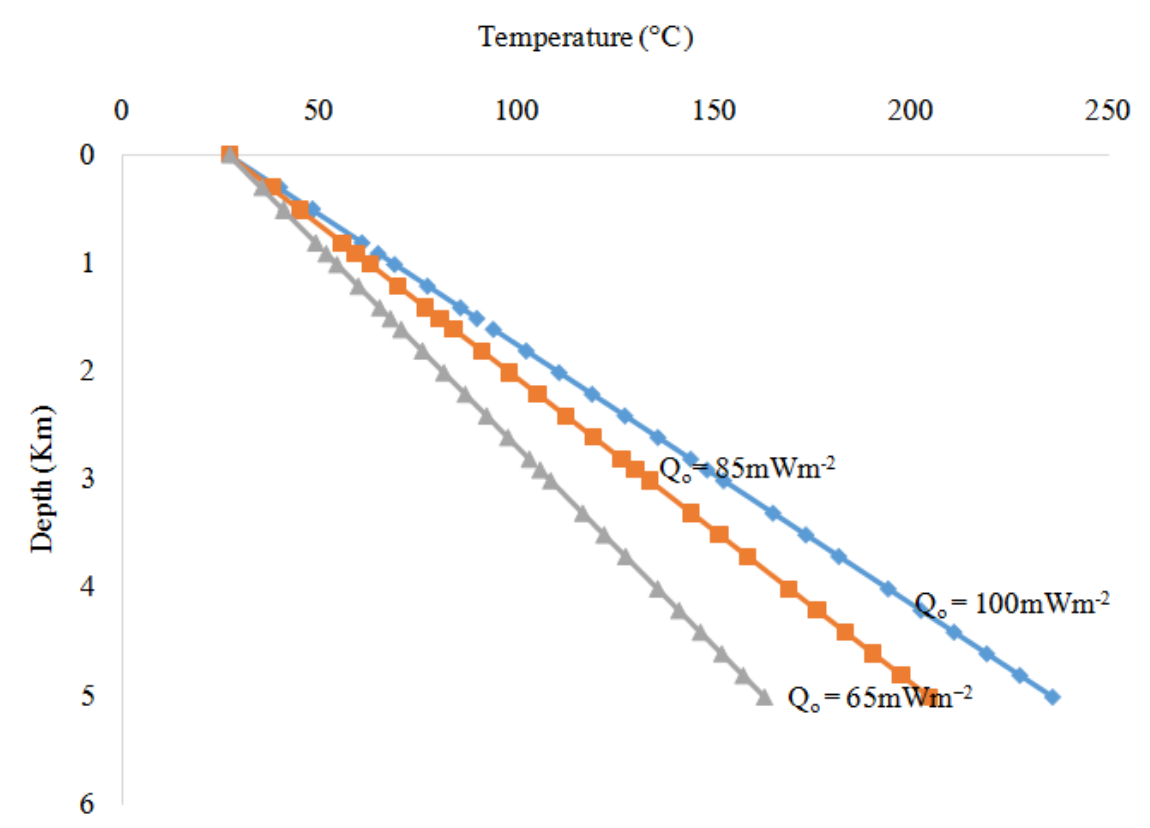

Fig 5. Geotherm for average thermal conductivity

\section{Discussion}

The computed temperature increases linearly with depth within the sediments. This is a normal expectation because temperature increases with depth. The properties controlling the temperature in sedimentary column are both internal and external. The internal properties are the conductivity, specific heat, density and radioactive heat generation. The external properties are basal heat flow into the column, surface temperature and erosion or deposition of sediments.

In order to test the accuracy of the model, the computed geotherm was compared with bottom hole temperatures obtained from four wells: Tuma-1 (well 1), Kanadi-1 (well2), Kinasar-1 (well 3) and Murshe-1 (well 4) in the studied area. The computed and measured temperatures for the four wells are shown in Table 3-5. Measured bottom hole temperatures are shown in column three against their corresponding depths in column two. The estimated bottom hole temperatures for the different scenarios are shown in columns 4,5 and 6 . The results of the three scenarios show that the combination of: maximum thermal conductivities and maximum heat flow, lower thermal conductivities and lower heat flow and average thermal conductivities and average heat flow as the input parameters for the model equations give the best fit to the measured temperatures in the four wells. Since the temperature variation in the basin is not constant, the other models might be good for other parts of the basin. The outcome of this study can be used to generate subsurface temperature for the entire Chad sedimentary basin without measuring the bore hole temperatures.

The measured and computed temperatures distribution in the sedimentary basins vary both vertically and spatially. The spatial variation in the temperature may be due to lithologies, basement structures, thermal conductivity and groundwater flow. Lithologies with low thermal conductivity like mudstone and shale in the Fika Formation are associated with high geothermal gradients while lithology with high thermal conductive (sandstone) in the Gongila and Bima Formations are associated with low geothermal gradients. The results show that temperature in a column of rock is controlled by several parameters, some internal and some external to the rock column. The internal parameters are the conductivity, specific heat, density and radioactive heat generation. External factors include heat flow into the column, the surface temperature and the rate at which material is removed from or added to the top of the column (erosion or deposition).

The results of the geothermal modelling can be used as an aid in interpreting heat flow patterns in the study area, thermal and hydrocarbon modelling. The subsurface heat flow can be calculated by multiplying the temperature gradient (slope of the graph) with the thermal conductivity values at a particular depth. Therefore, accurate geothermal heat flow is dependent on accurate determination of subsurface lithology distribution and their corresponding thermal conductivity values. 
Emujakporue Godwin Omokenu / Physics International 2016, 7 (2): 44.52 DOI: 10.3844/pisp.2016.44.52

Table 3. Computed temperatures with minimum thermal conductivity for the four wells

\begin{tabular}{|c|c|c|c|c|c|}
\hline Well & Depth $(\mathrm{Km})$ & $\begin{array}{l}\text { Measured temp. } \\
\left({ }^{\circ} \mathrm{C}\right)\end{array}$ & $\begin{array}{l}\text { Computed temp } \\
\text { with Q100 }\end{array}$ & $\begin{array}{l}\text { Computed temp } \\
\text { with Q65 }\end{array}$ & $\begin{array}{l}\text { Computed temp } \\
\text { with Q85 }\end{array}$ \\
\hline \multirow[t]{3}{*}{ Well 1} & 0.0 & 27 & 27.00 & 27.000 & 27.0000 \\
\hline & 0.5 & 46 & 51.33 & 42.815 & 47.6815 \\
\hline & 4.0 & 180 & 221.64 & 153.520 & 192.4520 \\
\hline \multirow[t]{4}{*}{ Well 2} & 0.0 & 27 & 27.00 & 27.000 & 27.0000 \\
\hline & 0.5 & 44 & 51.33 & 42.815 & 47.6815 \\
\hline & 1.5 & 77 & 99.99 & 74.445 & 89.0445 \\
\hline & 2.5 & 110 & 148.65 & 106.075 & 130.4075 \\
\hline \multirow[t]{4}{*}{ Well 3} & 0.0 & 27 & 27.00 & 27.000 & 27.0000 \\
\hline & 1.5 & 80 & 99.99 & 74.445 & 89.0445 \\
\hline & 2.0 & 95 & 124.32 & 90.260 & 109.7260 \\
\hline & 2.5 & 115 & 148.65 & 106.075 & 130.4075 \\
\hline \multirow[t]{3}{*}{ Well 4} & 0.0 & 27 & 27.00 & 27.000 & 27.0000 \\
\hline & 0.5 & 44 & 51.33 & 42.815 & 47.6815 \\
\hline & 3.5 & 140 & 197.31 & 137.705 & 171.7705 \\
\hline
\end{tabular}

Table 4. Computed temperatures with maximum thermal conductivity for the four wells

\begin{tabular}{|c|c|c|c|c|c|}
\hline Well & Depth $(\mathrm{Km})$ & $\begin{array}{l}\text { Measured temp. } \\
\left({ }^{\circ} \mathrm{C}\right)\end{array}$ & $\begin{array}{l}\text { Computed temp } \\
\text { with Q100 }\end{array}$ & $\begin{array}{l}\text { Computed temp } \\
\text { with Q65 }\end{array}$ & $\begin{array}{l}\text { Computed temp } \\
\text { with Q85 }\end{array}$ \\
\hline \multirow[t]{3}{*}{ Well 1} & 0.0 & 27 & 27.0000 & 27.0000 & 27.0000 \\
\hline & 0.5 & 46 & 44.5195 & 38.3875 & 41.8915 \\
\hline & 4.0 & 180 & 167.156 & 118.1000 & 146.1320 \\
\hline \multirow[t]{4}{*}{ Well 2} & 0.0 & 27 & 27.0000 & 27.0000 & 27.0000 \\
\hline & 0.5 & 44 & 44.5195 & 38.3875 & 41.8915 \\
\hline & 1.5 & 77 & 79.5585 & 61.1625 & 71.6745 \\
\hline & 2.5 & 110 & 114.5975 & 83.9375 & 101.4575 \\
\hline \multirow[t]{4}{*}{ Well 3} & 0.0 & 27 & 27.0000 & 27.0000 & 27.0000 \\
\hline & 1.5 & 80 & 79.5585 & 61.1625 & 71.6745 \\
\hline & 2.0 & 95 & 97.0780 & 72.5500 & 86.5660 \\
\hline & 2.5 & 115 & 114.5975 & 83.9375 & 101.4575 \\
\hline \multirow[t]{3}{*}{ Well 4} & 0.0 & 27 & 27.0000 & 27.0000 & 27.0000 \\
\hline & 0.5 & 44 & 44.5195 & 38.3875 & 41.8915 \\
\hline & 3.5 & 140 & 149.6365 & 106.7125 & 131.2405 \\
\hline
\end{tabular}

Table 5. Computed temperatures with average thermal conductivity for the four wells

\begin{tabular}{|c|c|c|c|c|c|}
\hline Well & Depth (Km) & $\begin{array}{l}\text { Measured temp. } \\
\left({ }^{\circ} \mathrm{C}\right)\end{array}$ & $\begin{array}{l}\text { Computed temperature } \\
\left({ }^{\circ} \mathrm{C}\right) \text { with Q100 }\end{array}$ & $\begin{array}{l}\text { Computed temperature } \\
\left({ }^{\circ} \mathrm{C}\right) \text { with Q165 }\end{array}$ & $\begin{array}{l}\text { Computed temperature } \\
\left({ }^{\circ} \mathrm{C}\right) \text { with Q85 }\end{array}$ \\
\hline \multirow[t]{3}{*}{ Well 1} & 0.0 & 27 & 27.023 & 27.0150 & 27.019 \\
\hline & 0.5 & 46 & 47.879 & 40.5715 & 44.747 \\
\hline & 4.0 & 180 & 193.871 & 135.4670 & 168.843 \\
\hline \multirow[t]{4}{*}{ Well 2} & 0.0 & 27 & 27.023 & 27.0150 & 27.019 \\
\hline & 0.5 & 44 & 47.879 & 40.5715 & 44.747 \\
\hline & 1.5 & 77 & 89.591 & 67.6845 & 80.203 \\
\hline & 2.5 & 110 & 131.303 & 94.7975 & 115.659 \\
\hline \multirow[t]{4}{*}{ Well 3} & 0.0 & 27 & 27.023 & 27.0150 & 27.019 \\
\hline & 1.5 & 80 & 89.591 & 67.6845 & 80.203 \\
\hline & 2.0 & 95 & 110.447 & 81.2410 & 97.931 \\
\hline & 2.5 & 115 & 131.303 & 94.7975 & 115.659 \\
\hline \multirow[t]{3}{*}{ Well 4} & 0.0 & 27 & 27.023 & 27.0150 & 27.019 \\
\hline & 0.5 & 44 & 47.879 & 40.5715 & 44.747 \\
\hline & 3.5 & 140 & 173.015 & 121.9105 & 151.115 \\
\hline
\end{tabular}

\section{Conclusion}

The 1-D steady-state heat conduction equation for four-layer model has been derived and applied to part of the Chad sedimentary basin. The temperature was computed for three different scenarios of low, maximum and average surface heat flow and thermal conductivity respectively. The computed temperature-depth profiles increase with depth. The most important internal properties of the sediment that affect the thermal 
structure of the basin are the radiogenic heat production and thermal conductivity. It was observed from the comparison of the measured and computed temperatures for the four wells that there is a good match for some of the models. Those models not fitting the four wells can be applied in other parts of the basin. The analytical determination of the temperature-depth profile gives useful understanding of the thermal state of the Chad sedimentary basin.

\section{Funding}

The research was solely financed by the author.

\section{Author's Contribution}

The author solely designed, modelled and interpreted the project.

\section{Ethics/Conflict of Interest}

There is no conflict of interest. The author did the work alone.

\section{References}

Ali, S. and D.M. Orazulike, 2010. Well logs-derived radiogenic heat production in the sediments of Chad basin, NE, Nigeria. J. Applied Sci., 10: 786-800.

Beardsmore, G.R. and J.P. Cull, 2001. Crustal Heat Flow: A Guide to Measurement and Modelling. 1st Edn., Cambridge University Press, New York.

Cacace, M., B.O. Kaiser, B. Lewerenz and M. ScheckWenderoth, 2010. Geothermal energy in sedimentary basins: What we can learn from numerical models. Chemie der Erde, 70: 33-46.

Dieokuma, T., G.H. Ming and E.D. Uko, 2013. Preliminary estimation of thermal conductivity in Bornu-Chad Basin, Nigeria. Eur. Scientific J., 9: 300-309.

Fowler, C.M.R., 2005. The Solid Earth: An Introduction to Global Geophysics. 2nd Edn., Cambridge University Press, Cambridge.
Genik, G.J., 1992. Regional framework structure and petroleum aspects of the rift basins in Niger, Chad and Central African Republic (C.A.R.). Tectonophysics, 213: 169-185.

Gibson, H., K. Stuwe, R. Seikel, D. FitzGerald and P. Calcagno et al., 2008. Forward prediction of temperature distribution direct from 3D geology models. Australian Geothermal Energy Conference.

Goff, F. and C.J. Janik, 2000. Geothermal Systems. In: Encyclopaedia of Volcanoes, H. Sigurdsson, (Ed). Academic Press, pp: 817-835.

Kaichi, S., 1984. A method of determining terrestrial heat flow in oil basinal areas. Tectonophysics, 103: 67-79.

Lowrie, W., 2007. Fundamentals of Geophysics. 1st Edn., Cambridge University Press, Cambridge.

Mussett, A.E. and M.A. Khan, 2000. Looking into the Earth: An Introduction to Geological Geophysics. 1st Edn., Cambridge University Press, Cambridge.

Nwankwo, C.N., A.S. Ekine and L.I. Nwosu, 2009. Estimation of the heat flow variation in the Chad Basin, Nigeria. J. Applied. Sci. Environ. Manage., 13: 73-80.

Okosun, E.A., 2000. A preliminary assessment of the petroleum potentials from southwest Chad Basin (Nigeria), Borno. J. Geol., 2: 40-50.

Petters, S.W. and C.M. Ekweozor, 1982. Petroleum geology of Benue trough and southeastern Chad Basin Nigeria. AAPG Bull., 66: 1141-1149

Rudnick, R.L., W.F. McDonough and R.J. O'Connell, 1998. Thermal structure, thickness and composition of continental lithosphere. Chem. Geol., 145: 395-411.

Safanda, J., 1985. Calculation of temperature distribution in two-dimensional geothermal profile. Studia Geoph. et Geod., 29: 197-207.

Stein, C.A., 1995. Heat Flow of the Earth. In: Global Earth Physics: A Handbook of Physical Constants, Ahrens, T.J. (Ed.), American Geophysical Union, Washington, ISBN-10: 0875908543, pp: 144-158.

Stuwe, K., 2008. Principles of heat flow modelling. Course Notes Heat Flow Intrepid Geophysics.

Turcotte, D.L. and G. Schubert, 2002. Geodynamics. 2nd Edn., Cambridge University Press, Cambridge. 